\title{
QUALITY OF BEET JUICE AND ITS LIQUOR DURING BEET SUGAR PROCESSING. \\ Al-Barbari,F.S.*;E.G.I.Mohamed. ${ }^{\star *}$; M. A. Abd - EL - Rahman*; and Samy I. Elsyiad*. \\ ${ }^{*}$ Food Science \& Technology Dept., Fac. Agric., Assiut Univ., Egypt \\ ${ }^{* \star}$ delta sugar factory, Kafr EL-Sheikh Governorate, Egypt.
}

\begin{abstract}
This investigation was carried out to study the quality of beet juice and its liquors during beet sugar processing. Sample of sugar beet roots and slices were taken from the research fields of Delta sugar company. The samples of moist past, raw juice, clear juice, syrup and masscuites A, B and C were obtained from processes of Delta sugar factories during the 2013 working season .

The samples were analyzed for the following:

Moisture, ash, sucrose, total soluble solids, $\alpha$ - amino nitrogen, sodium, potassium, purity, sucrose loss and $\mathrm{pH}$.

It can be seen from the presented data that

1 - Quality of sugar beet ranged from $75.20 \%$ in the first season to $82.80 \%$ at the end of the season.

2 - Purity of beet juice ranged from 85.54 to $87.75 \%$.

3 - The purity increased by $2.8 \%$ after evaporation process.

4 - Beet roots must be sliced with sharp knives to minimize tearing of the beet cells.

Keywords: Sugar beet (Beta vulgaris L.) , sucrose, beet juice, Quality .
\end{abstract}

\section{INTRODUCTION}

Sugar beet (beta vulgaris L.) is considered as one of the most important crops, not only for sugar producing but also for the other main production, fodder and organic matter for the soil. However, sugar beet is grown under rather moderate climates, in the northern hemisphere in particular, Europe, Canada and Russia. Also, sugar beet has been rather recently introduced in the Egyptian agriculture and industrial activities. Yet the area planted with sugar beet and the produced white sugars are increased. The annual consumption of population from sugar is 2.6 million tons. So that sugar beet is becoming a growing source of sugar production in Egypt (Center Sugar Crops, Ministry of Agriculture's 2012).

Sugar beet is a biennial plant (a plant requiring two years for a full life cycle). In the first year of growth, the root (the part containing sucrose) and leaves grow. In the second year, the sugar beet flowers and produces seed. Seed is planted in the spring, and sugar beet is harvested in the late fall or early winter. Typically, sugar beet needs between six to eight months to grow and become ready for processing in the factory Asadi (2007).

Sugar beet is considered the second sugar crop for sugar production in Egypt after sugar cane. Recently, sugar beet crop has been an important position in Egyptian crop rotation as a winter crop not only in fertile soils, but also in poor, saline, alkaline and calcareous soils El-Hawary, M.A. (1999).

During the last century, both industries have grown considerably. World sugar production has increased from approximately 10 million tons in 1900 to 
about 150 million tons in 2005. The beet sugar industry plays an important role in the economy of beet sugar producing Countries, which employ large numbers of people to grow sugar beet, to produce sugar, and to support sugar-related areas such as sales, service, and research.

Egypt production from sugar is about $(1,897,700)$ million tons from both sugar cane (985081tons) and sugar beet (912620 tons) on juice season of 2011 Gomaa (2013). There are over 500 beet-sugar factories in the world. About $40 \%$ of the world's sugar production is from beet, and $60 \%$ is from cane. The climates of most sugar producing countries are suitable for growing either beet (in moderately cold areas) or cane (in tropical areas). In only a few countries (United States, Iran, Spain, Egypt, and Pakistan), the growing conditions are suitable for both crops. Beet sugar (sugar made from sugar beet), cane sugar (sugar made from sugarcane), and refined sugar (sugar made from raw sugar) are similar in shape, taste, and other chemical and physical properties. Both beet and cane sugar that we use in cooking are pure sucrose with $99.95 \%$ purity, so the old belief of placing a higher value on one of them is not true. Sugar producers are not required to mention the source of the sugar on the label, so both are used interchangeably in households and in sugar-added food products Asadi (2007).

The principle objective of this work was studying the optimal conditions of the sugar beet extraction, adding the milk of lime and carbonation process and the steam consumption during operation of sugar factories.

\section{MATERIALS AND METHODS}

\section{Materials}

\section{Experimental procedures:}

The experimental was carried out at laboratories of Delta Sugar Company, Kafr El-Sheikh Governorate, Egypt, during (2013) harvest season.

Samples of sugar beet roots (Beta vulgaris $L$.) and slices were taken from the research fields of Delta Sugar Company. The samples of moist past, raw juice, clear juice, syrup and masscuites (A), (B) and (C) were obtained from processes of Delta Sugar factories during the seasons of (2013)

\section{Analytical methods}

\section{Determination of chemical constituents:}

Moisture content:

The moisture content was determined by drying samples to constant weight at $105^{\circ} \mathrm{C}$, using the air oven-drying method according to A.O.A.C. (1990).

\section{Ash content}

Ash content was determined using Muffle furnace with digital PID controller, model, CWF-11/13 max, $1100 \stackrel{\circ}{\mathrm{C}}$ at $550{ }^{\circ} \mathrm{C}$ according to the method of A.O.A.C (1990).

\section{Sucrose content:}

Sucrose content was determined using automatic saccharimeter on a lead acetate basis according to procedure of Delta Sugar Company, Le Docte (1977). 


\section{Reducing sugar:}

Reducing sugar content of beet roots samples were determined using Ofner's volumetric methods as described in A.O.A.C. (1990)

Total soluble solids (T.S.S):

Total soluble solids of fresh samples were determined using fully automatic digital refractometer, model ATR-S (04320), 0 - 95\% Brix, temperature compensation 15 to $40 \stackrel{\circ}{ } \mathrm{C}$ according to procedure of Delta sugar Company.

\section{Alpha amine nitrogen, Sodium and potassium}

Alpha amine nitrogen, sodium and potassium were determined using venma, Automation BV Analyzer IIG-16-12-99, 9716JP/ Groningen / Holland. Temp. $18-30 \circ \mathrm{C}$, surrounding humidity max. $70 \%$ according to Brown and Lillan (1964), the results calculated as milli equivalents / $100 \mathrm{~g}$ beet.

\section{Juice purity and beet quality:}

Purity $=($ sucrose $\% .100) /($ T.S.S $\%)$

Quality $=(\mathrm{SR} .100) / \mathrm{pol} . \mathrm{SR}=($ pol-0.29) $-0.343(\mathrm{k}+\mathrm{Na})-\alpha \mathrm{N}(0.0939)$

Where:

$\mathrm{Pol}=$ Sucrose $\%, \mathrm{~K}=$ Potassium, $\mathrm{Na}=$ Sodium, $\alpha-\mathrm{N}=$ Alpha-amino nitrogen,

$\mathrm{SR}=$ Sugar recovery and T.S.S $=$ total soluble solids

The procedures according to Delta Sugar Company described by Silin and Silina (1977) and Sapronova et al. (1979).

pH measuring:

$\mathrm{pH}$ measuring by using digital bench $\mathrm{pH}$-meter, model $\mathrm{pH}-526 /$ sentix 20/AS- DIN / SIN / STH / 650 according to procedure of Delta sugar Company.

\section{RESULTS AND DISCUSSION}

\section{Chemical and technological characteristic of beet juice}

Sugar beet (the raw material of the beet sugar factory) composition is important to both the sugar beet farmer and the factory. Sugar (sucrose) and non-sugar (non-sucrose) content determine the quality of the sugar beet where, high sugar and low non-sugar content is desirable. So it is important to evaluate the chemical and technological characteristic of beet juice in order to evaluate the quality of beet roots for sugar production.

Chemical and technological characteristic of beet juice during the beet campaign (beet-processing period) are given in table (1). Sucrose content of sugar beet juice ranged between $17.33 \%$ and $19.35 \%$ during the beet campaign. Similar results were recorded by Abou EL-Magd et al (2004), Asadi (2007) and Gomaa (2009). They reported that sucrose content of beet juice ranged between $17.5 \%$ to $19.57 \%$. And this the optimal values for the sugar factories. From the data shown in the same table, it could be noticed that the total soluble solids content of beet juice ranged between $19.80 \%$ to $22.62 \%$. The present result are in agreement with findings of Zalat (1993) and Hozayen (2002). They reported that (T.S.S) of sugar beet juice ranged between $15.54 \%$ and $23.60 \%$. 
Relatively higher reducing sugar values were observed in the sugar beet juice ranged from 0.45 to $0.55 \%$. But the optimal sugar beet juice always contain 0.05 to $0.1 \%$ of reducing sugars. These data shown in table (1) were comparable with those reported by many authors Abou-Shady (1994), Abd EL-Mohsen (1996) and Gomaa (2009) found that the reducing sugar ranged between $0.25 \%$ to $1.55 \%$ (by dry weight) .

Table (1): Chemical and technological characteristic of beet juice during processing

\begin{tabular}{|l|c|c|c|}
\hline characters & $\mathbf{1}^{\text {st }}$. of season & Mid. Of season & End of season \\
\hline Sucrose \% & 17.33 & 18.81 & 19.35 \\
\hline Brix (T.S.S) \% & 19.80 & 21.40 & 22.62 \\
\hline Reducing sugar & 0.45 & 0.48 & 0.55 \\
\hline Ash & 0.65 & 0.71 & 0.77 \\
\hline Sucrose recovery (SR) & 14.31 & 15.96 & 15.10 \\
\hline Sucrose loss (SL) & 3.02 & 2.85 & 4.25 \\
\hline Purity & 87.75 & 87.89 & 85.54 \\
\hline Beet quality & 75.20 & 84.90 & 82.80 \\
\hline pH & 6.10 & 6.23 & 5.90 \\
\hline
\end{tabular}

Table (1) show that ash content ranged between 0.65 to $0.77 \%$ in sugar beet juice. The result obtained are in good agreement with Hozayen (2002) and Gomaa (2009). who reported that ash content of beet juice ranged between 0.52 to $0.77 \%$.

Sucrose recovery depended on the some factors such as sucrose, $\mathrm{K}$ and $\alpha-\mathrm{N}$ content . It has positive correlation with sucrose content and negative correlation with $\mathrm{Na}, \mathrm{K}$ and $\mathrm{\alpha}-\mathrm{N}$ content of sugar beet juice.

From table (1) it could be noticed that sucrose recovery of sugar beet juice ranged from 14.31 to $15.96 \%$ during the beet campaign that carried out to knew comparative analysis between beet laboratory (predicted) and factory laboratory (true). These findings are in agreement with Gomaa (2009) who mentioned that the sucrose recovery (white sugar) of beet juice ranged from 14.19 to $15.16 \%$ in beet laboratory.

From table (1) it could be noticed that the loss of sucrose in beet wastes ranged from $3.02 \%$ in the first of the season and increased to $4.25 \%$ at the end of season due to increase the sugar losses in beet pulp, in the filter cake and in the final molasses. So it is recommended to carry out comparative analysis between beet laboratory and factory laboratory to find out what effects a short storage of a few hours or a storage time of more than 24 hours have on the losses.

These findings are agreement with results reported by Gomaa (2009) that the losses of sucrose in wastes were ranged from 3.06 to $4.12 \%$ in the beet juice. From data in table (1), it could be said that by decrease the losses of sucrose in wastes, the sugar produced as white sugar increase.

The purity of sugar beet juice is defined as the ratio of sucrose to total solids, as a percentage. The data illustrated in table (1) shows that the purity of beet juice ranged from 85.54 to $87.75 \%$. It can be said that, the main goal of the sugar factory is to separate non-sugar from sugar to improve the beet 
juice purity to the extent that sugar with $100 \%$ purity is produced. Also, by increase the purity of beet juice would make sugar beet processing much faster and easier. These results were supported by Asadi (2007) who reported that the purity of beet juice usually ranged from 85 to $88 \%$ in atypical washed beet (beet without tare).

From table (1) it can be recognized very clearly that the beet quality depends on the case of beet roots, healthy or injured. So, that the beet quality decrease in the case of arising alkaline ( $\mathrm{K}$ and $\mathrm{Na}$ content) and nitrogen content, during the first and the end days of campaign of the factory operated. So, it ranged between $75.20 \%$ it the first of season and $82.80 \%$ at the end of season. The results are in agreement also with those reported by Gomaa (2009) who found that the quality of beet ranged from 78.63 to $82.95 \%$ during the period of the beet processing.

The result are presented in table (1) revealed that the $\mathrm{pH}$ values of sugar beet juice ranged between 5.9 to 6.23 during the beet campaign. These results are in agreement with Gomaa (2009) who reported that the $\mathrm{pH}$ of sugar beet juice was 6.51 .

\section{Effect of beet slices on extraction process.}

Slicing beets is the process of cutting beets into long, thin strips called cossettes. The main function of the beet slicing operation is to improve the diffusion process and the removal of sucrose from beets. This achieved mainly due to the increase of the surface area of the beets and so maximize the following. The contact area between the beet cells and the water in the diffusion.

The movement of the sugar from the cells to diffusion juice. Table (2) showed the effect of beet slices on the extraction process. it could be noticed that the beets must be sliced with sharp knives to minimize tearing of the beet cells.

Torn cells allow more impurities (non-sugar) to be diffused into the surrounding juice, causing an increase in non-sugar and consequently, a reduction in juice purity (sucrose content as \% of dry substance). Tearing also creat more foams because of saponin release in the juice, which is undesirable.

Table (2) Effect of beet slices on extraction process.

\begin{tabular}{|l|c|c|c|}
\hline \multirow{2}{*}{ characters } & \multicolumn{3}{|c|}{ Knives beet slicers 200 $\mathbf{9 9} \mathbf{~ m m}$} \\
\cline { 2 - 4 } & 28 division & 25 division & 23 division \\
\hline Geometry & V- shaped & V- shaped & V- shaped \\
\hline Length cm & 7.65 & 6.50 & 6.30 \\
\hline Clearance mm & 7.19 & 8.10 & 8.69 \\
\hline Mush content \% & 1.35 & 3.85 & 5.77 \\
\hline Thickness mm & 4.25 & 5.75 & 6.25 \\
\hline
\end{tabular}

Table (2) also indicates that, the most important in producing quality cossettes are the types of knives used. Most knives have $V$ shape. Each knife consists of several V- grooves, called division. A standard knife $200 \mathrm{~mm}$ long and $89 \mathrm{~mm}$ wide. The length of cossettes depends on the type of knife 
divisions where. Knife of 28 division is more length 7.65 and knife of 23 division is less length $6.30 \mathrm{~cm}$

The clearance in knives of 28 division $7.19 \mathrm{~mm}$ is less than in knives of 25 division $8.10 \mathrm{~mm}$ and knives of 23 division $8.69 \mathrm{~mm}$.

From table (2) the mush content is the ratio of the mass of cossettes less than $10 \mathrm{~mm}$ long to the total cossette mass $(100 \mathrm{~g})$. The knife of 28 division is less mush content $1.35 \%$ and less thickness $4.25 \mathrm{~mm}$. while the knives of 25 and 23 division is more mush content and thickness $3.85,5.75$ and 5.77, 6.25 respectively; The result in table (2) are agree with Silin and Silina(1977) and Asadi (2007) they reported that, good cossettes have Silin number of 6 to 10 $\mathrm{m}$, good cossettes are shorter than $10 \mathrm{~cm}$ and thinner than $5 \mathrm{~mm}$.

Also the desired characteristics for high quality cossettes are as follows. Uniform width 3 to $6 \mathrm{~mm}$ thick, and $\mathrm{V}$ shape

Uniform length 30 to $60 \mathrm{~mm}$ long.

Good operations require that the mush content be smaller than 2 to $5 \%$.

Effect of chemical treatment on beet juice during extraction and clarification process.

Data in table (3) it could be noticed that, the chemical treatment of beet juices during clarification and extraction process depending on the beet cases (healthy or injured) and the weather conditions.

The parameters of sugar beet juices in the first and midel of season considered normal values and close to the true values. The brix of raw juice ranged from $18.36 \%$ to $18.54 \%$ in the first and the midel season respectively. Also, the brix of clear juice (before delimed) ranged from 17.56 to $18.05 \%$ of the same periods of season.

While the brix of raw juice and clear juice increased to 19.90 and $18.88 \%$ respectively, of the end season. Also, an increase of the purity ( at the end of season ) of sugar beet apparently when beet roots remains un processed for more than a week, so the beet becomes badly damaged by microorganisms, especially the mesophilic types, mainly leuconostoc bacteria, which gradually consume the sugar and convert some of it into dextran.

Table (3): Effect of chemical treatment on beet juice during extraction and clarification process.

\begin{tabular}{|l|c|c|c|c|c|c|}
\hline \multirow{2}{*}{ Parameter } & \multicolumn{2}{|c|}{$\mathbf{1}^{\text {st }}$. of season } & \multicolumn{2}{c|}{ Midel of season } & \multicolumn{2}{c|}{ End of season } \\
\cline { 2 - 7 } & Raw juice & clear juice & Raw juice & clear juice & Raw juice & clear juice \\
\hline Brix & 18.36 & 17.56 & 18.54 & 18.05 & 19.90 & 18.88 \\
\hline Purity & 85.70 & 87.40 & 87.00 & 89.20 & 87.20 & 89.70 \\
\hline Reducing sugar & 0.25 & 0.15 & 0.48 & 0.22 & 0.55 & 0.30 \\
\hline Color \% brix & 25000 & 1200 & 27000 & 1400 & 30000 & 1800 \\
\hline Hardness & 785 & 130 & 840 & 175 & 910 & 230 \\
\hline pH & 6.3 & 9.3 & 6.4 & 9.0 & 5.6 & 8.8 \\
\hline
\end{tabular}

The purity of raw juice ranged from 85.70 to $87.20 \%$ during the beet campaign. But the purity of clear juice increased due to non-sugar elimination in purification and clarification process and ranged from 87.4 of the first of season to $89.7 \%$ at the end of season. These results are in agreement with Asadi (2007) who are reported that, the diffusion juice (raw juice) usually has about $15 \%$ dry substance and its purity ranged from 85 to $88 \%$. while clear 
juice has dry substance lower than diffusion juice by about $0.5 \%$ and about 3 units higher than in purity .

Also, from table (3) it could be showed that low values of reducing sugar in both raw and clear juice in the first of season $0.25 \%$ and $0.15 \%$ respectively; and increased at the end of season to $0.55 \%$ for raw juice and $0.30 \%$ for clear juice due to some of sucrose hydrolyzed to invert sugar. Burba and Nitzschke (1973) and Schiweck and Busching (1974) reported reducing sugar ratios in fresh beet of between $1.5: 1$ and $1.7: 1 \%$ respectively;

The data in table (3) showed that the raw juice has high colour ranged from 25000 to 30000 color \% brix due to colorant formed by oxidation occurs when the beet juice reacts with the oxygen in the air, the same thing happens with cossettes when it is exposed to air immediately after slicing. But the clear juice has lower color then raw juice 1200 to 1800 color \% brix , due to most of these colorants precipitate with lime are removed during purification . The results are lowest to those reported by Arslanoglu and Tumen (2012) who stated that, color of thin juice was 2720 (ICUMSA International Commission for Uniform Methods of Sugar analysis).

Hardness is the amount of soluble salts of calcium and magnesium in the juice. From table (3) it could be noticed that, high hardness values of raw juice due to long campaign period. Hardness of raw juice ranged from 785 to $910 \mathrm{mg} \mathrm{CaO} / \mathrm{L}$. it could be also said that, hardness can get too high when a factory processes damaged beet. The hardness content of thin juice from $130 \mathrm{mg} \mathrm{CaO} / \mathrm{L}$ to $230 \mathrm{mg} \mathrm{CaO} / \mathrm{L}$ is normal and also decreased by purification process. These results in agreement with finding of Asadi (2007), who reported that, the hardness content of thin juice depends on where the sugar beet is grown. A hardness content of 50 to $200 \mathrm{mg} / 100$ dry substance is normal.

The results in table (3) indicated that the $\mathrm{pH}$ of raw ranged from 5.6 to 6.4 and this is the optimum $\mathrm{pH}$ for raw juice but it may be slightly lower by microbiological activity due to the production of organic acid, especially; when the beet campaign increased (at the end of season).

Also, the $\mathrm{pH}$ of thin juice is ranged from 8.8 to 9.4 and it is optimum values for good process.

\section{Effect of steam consumption in the evaporator on the cast of sugar} factories :

These results are very high values with compared to, that reported by Asadi (2007) who reported that running the evaporation station efficiency is one of the best ways to reduce cost in tody's sugar factories especially with the recent sugar fuel cost. In the United States, the steam consumption of the factories has recently been decreased to 25 and $28 \%$ on beet. Also in newly built European factories, steam consumption on beet has been as efficient as $10 \%$ on beet, so it is necessary to lower, by all means the energy demands of the factory. 
Table (4):effect of steam consumption in the evaporator on the cast of sugar factories

\begin{tabular}{|l|c|c|c|}
\hline Parameter & $\mathbf{1}^{\text {st }}$ season & Midel season & End season \\
\hline Steam consumption & 36.63 & 37.18 & 43.77 \\
\cline { 2 - 4 } & 36.37 & 37.31 & 45.50 \\
\cline { 2 - 4 } & 36.97 & 40.10 & 47.10 \\
\hline average & 36.57 & 38.20 & 45.46 \\
\hline
\end{tabular}

Changes in beet juice quality and it is liquors during evaporation and crystallization process :

Data in table (5) indicates the changes in beet juice quality (thin and thick juice) after evaporation and masscuites after crystallization. Thin juice is the juice obtained after purification process. It is also clarified juice or evaporated supply juice which may have been delimed or sulfitated.

Thick juice is concentrated juice following evaporation and masscuite is a mixture of crystals in pan boiling or cooling crystallizer.

Table (5):Changes in beet juice quality and it is liquors during evaporation and crystallization process .

\begin{tabular}{|l|c|c|c|c|c|}
\hline & & & \multicolumn{3}{|c|}{ Massecuite } \\
\cline { 4 - 6 } Parameter & Thin juice & thick juice & A & B & C \\
\hline Brix & 17.20 & 71.25 & 93.00 & 93.50 & 95.00 \\
\hline Purity & 88.50 & 91.30 & 93.50 & 86.50 & 79.70 \\
\hline pH & 9.10 & 8.80 & 8.60 & 8.60 & 8.30 \\
\hline Density & 1.08 & 1.35 & 1.47 & 1.48 & 1.050 \\
\hline \% on beet & 130 & 32 & 29 & 18 & 10 \\
\hline
\end{tabular}

Results obtained in table (5) shows clearly an increase in brix by $54.05 \%$ due to water evaporating from juice. Also an increase in purity by $2.8 \%$ and reduction in $\mathrm{pH}$ by 0.3 between thin juice and thick due to volatile non sugar substance such as ammonia evaporation from juice.

The density in thin and thick juice can be considered quite normal but the amount of thin juice $130 \%$ on beet and thick juice $32 \%$ on beet can be considered higher than the normal amount $110 \%$ on beet and $26 \%$ on beet for thin and thick juice respectively; according to heat balance sheet of Delta Sugar Company. These results in agreement with Asadi (2007) who reported that, for thin juice, the typical purity value ranges from 85 to $92 \%$ and brix from 14 to $15 \%$. Thin juice low in hardness and color and with $\mathrm{pH}$ of 8.8 to 9.0 while thick juice with about 65 to $70 \%$ brix and about $8.7 \mathrm{pH}$ with high color. From table (5) it could be indicate that, to recover the maximum amount of sugar from thick juice, beet sugar factories use a three stages of crystallization.

Process, first stage (A) called the white side, and second (B) and third (C) stages called the raw side. Data in table (5) shows atypical sugar - end for massecuites $A, B$ and $C$ to get the maximum amount of sugar crystals from centrifugals of massecuites. The results in table (5) in agreement with IPRO (1992) for sugar boiling /mass blance. 


\section{REFERENCES}

Abd El-Mohsen, N.E. (1996).Chemical and technological studies on sugar beet.Egypt. J. Food Sci., 24(1): 1-14.

Abou-Shady, Kh.A.A.(1994).Chemical and technological studies on sugar beet and its wastes .M.Sc. Thesis, Fac. of Agric., Al-Azhar Univ.

Abou EL- Magd, B.M; Youssif, S. and Nariman, O.A.(2004). Effect of some chemical tretments on the chemical quality and storability of sugar beet roots after harvest . Egypt . J. APP. Sci, 19(11) : $263-277$.

A.O.A.C.(1990)."Official Methods of Analysis. Association of Official Analytical Chemists. Washington 25 D.C., USA.

Arslanoglu, H. and Tumen, F.(2012). A study on cations and color removal from thin sugar juice by modified sugar beet pulp

Asadi, M.(2007).Beet-Sugar Handbook. John Wiley and Sons, Inc., Hoboken, New Jersey.

Brown, J.D and Lilland, O. (1964).Rapid determination of potassium and sodium by flam photometry.Proc. Amer. Soc. Hort. Sci., 48, 341-316

Center Sugar Crops, Ministry of Agriculture, January (2013).

Burba, M. and Nitzschke, U. (1973) Stoffwechselphysiologische Untersuchungen an Zuckerrüben während der Vegetationszeit. III: Glucose, fructose, galactose und raffïnose. Zucker 26, 356-365.

El-Hawary, M.A., (1999). Influence of nitrogen, potassium and boron fertilizer levels on sugar beet under saline soil condition. J. Agric. Sci. Mansoura Univ.Egypt, 24: 1573-1581.

Gomaa, S. (2009).Effect of calcium hydroxide and acetic acid on the rat of deterioration and dextran formation during sugar beet storage. M.Sc. Thesis, Sugar Techn. Research Inst., Assiut Unive.

Gomaa, S. (2013).Effect of dextran on sugar beet quality and sugar manufacture. Ph.D. Thesis, Sugar Techn. Research Inst., Assiut Unive.

Hozayen, A.M.A. (2002).Technological and chemical studies on sugar beet roots. M.Sc. Thesis, Fac. of Agric. Ain Shams Univ.

IPRO (1992).Industries Project GMBH for Sugar Boiling Diagram/Mass Balance. Postfach 2638, 3300Branschweig .

Le Docte, A. (1977). Commercial determination of sugar in sugar beet using the socks sugar J., 29, 488-492.

Sapronova, A.; Joshman, A. and loseava, V. (1979).General technology of sugar and sugar substances.Pischevayapromyshennost pub.Moscow, $464 \mathrm{p}$.

Schiweck, H. and Büsching, L. (1974) Das Verhalten von Glucose und Fructose während der Zuckerfabrikation. Zucker 27, 122-128.

Silin, P.M. and N.P.Silina (1977).Chemical control in sugar technology.Food Technol., pub. USSR, pp. 120-126.

Zalat, S.S. (1993). Effect of some cultural practices on sugar beet. Ph.D. Thesis, Fac. of Agric. Zagazig Univ. 
Al - Barbari, F. S. et al.

جودة عصير البنجر ورحيقة خلال تصنيع البنجر البرا

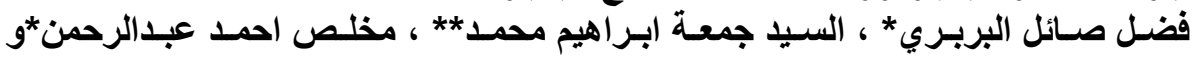

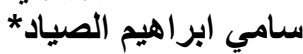

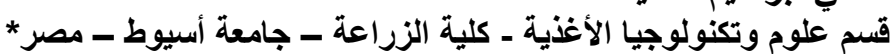

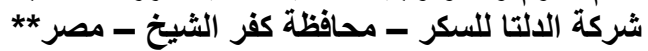

تناولت الدراسة في هذا البحث جودة عصير البنجر ورحيقة خلال مر احل التصنيع ـ حيث

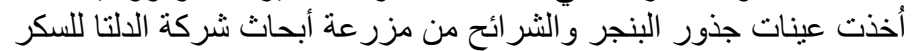

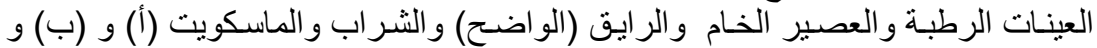

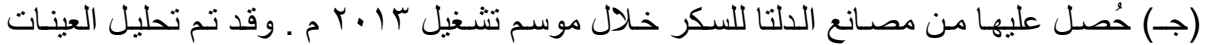
كالتالى : (الرئي

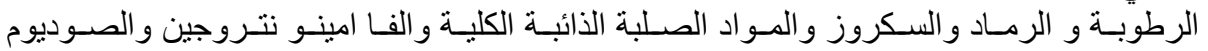

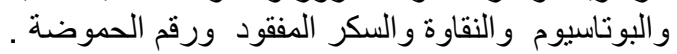
واظهرت نتائج التحليل مايلي :

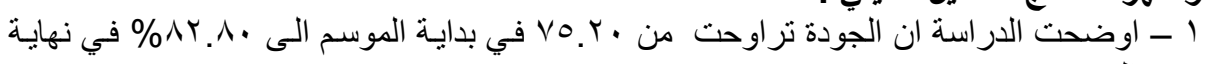

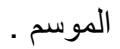

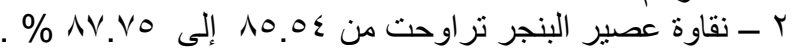

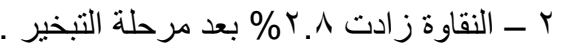

r- يجب تقطيع جذور بنجر السكر بالسكاكين الحادة لتقليل تمزيق الخلايا . 